\title{
Studies of Climate Change in the Yukon River Basin: Connecting Community and Science Through a Unique Partnership
}

\section{Introduction}

An exciting new partnership between the U.S. Geological Survey (USGS) and the Yukon River Inter-Tribal Watershed Council (YRITWC) is yielding critical data for the assessment of climate change effects in the Yukon River Basin. The foundation of this partnership is a shared interest in the current and future water quality of the Yukon River and its relation to climate. The USGS began a landmark study of the Yukon River and its major tributaries in 2000. A key objective of this study is to establish a baseline dataset of water quality, which will serve as an important frame of reference to assess future changes in the basin that may result from a warmer climate.

Communications between the USGS and the YRITWC were established in 2005 when the YRITWC began building a steward-based Yukon River water-quality program. The YRITWC is an international nonprofit that was forged by the world's largest international treaty between Indigenous governments. Seventy Tribes of Alaska and First Nations of the Yukon Territory have become signatories to the YRITWC's Inter-Tribal accord, which serves to reinforce their collective interest and stewardship of the Yukon River. YRITWC's mission is to monitor, preserve, and protect the health of the Yukon River Basin. Through a collaborative effort with the USGS, the YRITWC has developed and implemented a basin-wide water-quality program modified from and expanding upon the USGS study. This unique partnership between the USGS and the YRITWC provides mutual benefits by fostering outreach efforts that have been essential toward community empowerment, and by providing scientific data covering large remote regions that would be challenging for USGS scientists alone to sample with this frequency and extensive spatial coverage.

The Yukon River Basin (YRB) covers subarctic and arctic terrain in Canada and Alaska, is the fourth largest drainage basin in North America, and is roughly twice the size of California (fig. 1). The sheer scale of the YRB presents a unique set of logistical challenges that have been met by the collaborative partnership between the USGS and the YRITWC.

\section{Local Concerns About Climate Change}

The communities living within the YRB have many concerns about a rapidly warming climate and how these changes will affect traditional ways of life and the availability of future resources. As the warming trends continue, the climate is becoming drier (Hinzman and others, 2005), forest fires have been increasing (Kane and others, 2006), and permafrost is thawing (Jorgenson and others, 2006). Permafrost thaw will likely lead to changes in the groundwater flows (Walvoord and

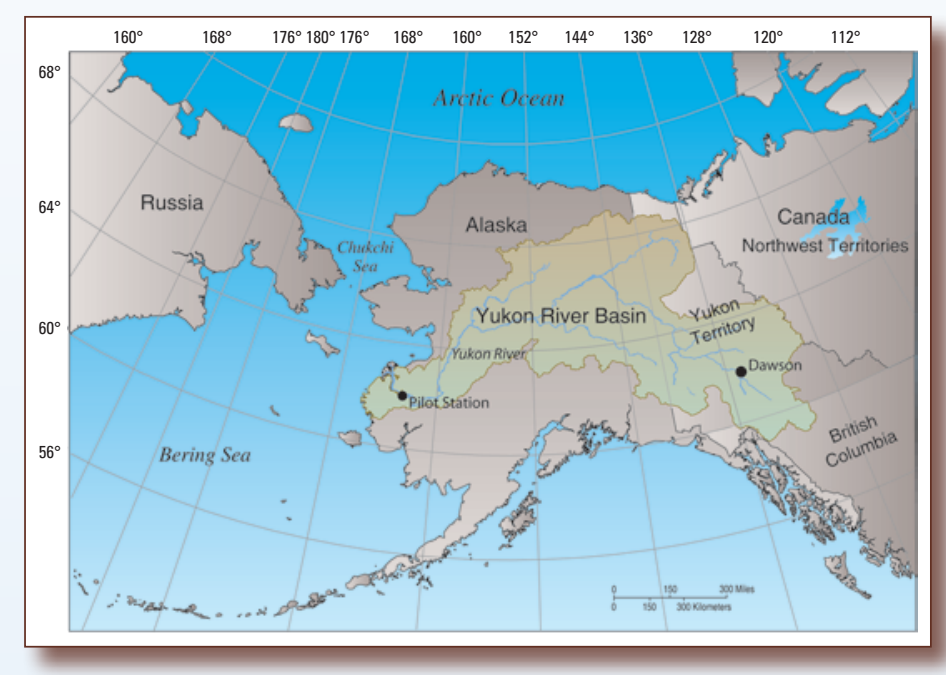

Figure 1. Location of the Yukon River Basin in Canada and Alaska.

Striegl, 2007) and the quantity and quality of the rivers, streams, and lakes (Striegl and others, 2005; 2007). These fundamental physical and chemical changes ultimately may affect the migratory routes of spawning salmon and animals, such as moose and waterfowl. Other concerns related to a warming climate are structural effects caused by the settling of building foundations anchored in permafrost and the shorter ground transportation season due to shorter periods of ice cover on the river.

\section{Addressing Concerns Through the USGS/YRITWC Partnership}

The overarching goal of the YRITWC/USGS partnership is to train community members to collect water-quality and environmental data across the Yukon River Basin throughout the year. The YRITWC/USGS partnership is a shared achievement in the collection and interpretation of unbiased scientific data to better understand the environment. The project was created across governments and communities to facilitate the development of a unique long-term database essential to studies focusing on climate change.

\section{Approach}

Under the direction of the USGS, the YRITWC developed a water-quality monitoring program that uses the USGS sampling and monitoring protocols (U.S. Geological Survey, variously dated). The YRITWC program provides spatial coverage of sampling sites in the YRB and augments hydrologic information collected at USGS streamflow-gaging stations (fig. 2). The YRITWC trains local volunteers to collect water-quality data and samples from the Yukon River and its major tributaries. 
Water-quality samples include the in-place measurement of $\mathrm{pH}$, specific conductance, temperature, and dissolved oxygen in addition to the collection and processing of a suite of water samples for laboratory analyses by the USGS.

In conjunction with the YRITWC field campaign, and critical to the success of the program, the USGS National Research Program laboratories in Boulder, Colorado, provide analytical support by measuring dissolved organic carbon, greenhouse gases, major ions, nutrients, trace metals, and water isotopes. In addition, USGS scientists train YRITWC personnel in field data and sample collection.

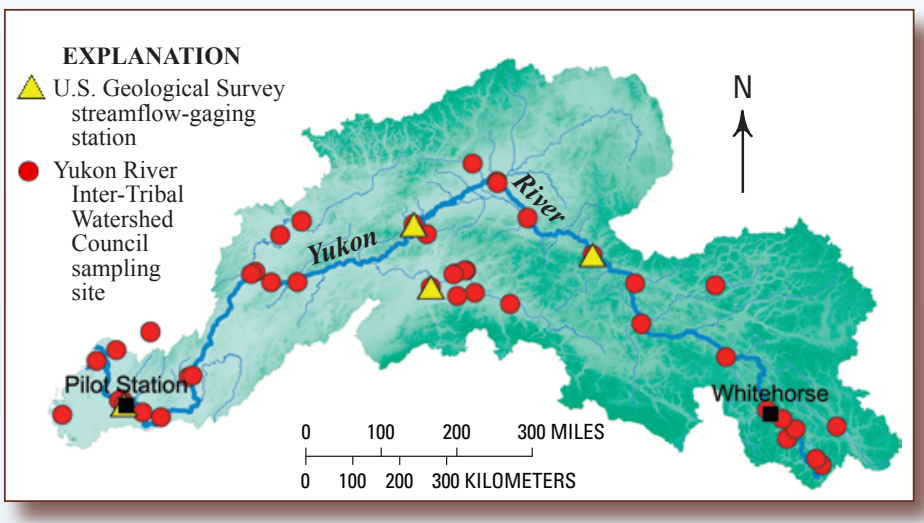

Figure 2. USGS streamflow-gaging stations and collocated YRITWC sampling sites across the Yukon River Basin.

\section{Resources}

The scope of the YRITWC monitoring effort is determined, in part, by available funding. In March 2006, YRITWC began monitoring the Yukon River Basin between Dawson City, Yukon Territory, and Pilot Station, Alaska. Funding was provided by an Administration for Native Americans grant for regulatory enhancement on the United States side of the YRB, and discretionary resources were used to establish the Canadian side of the YRB.

In early 2007, YRITWC received a grant from Environment Canada (EC) to conduct a workshop with EC, USGS, Yukon Territory Government, and Water Survey of Canada. At the workshop, interested First Nations joined the YRITWC to assist in ongoing water-quality monitoring efforts.

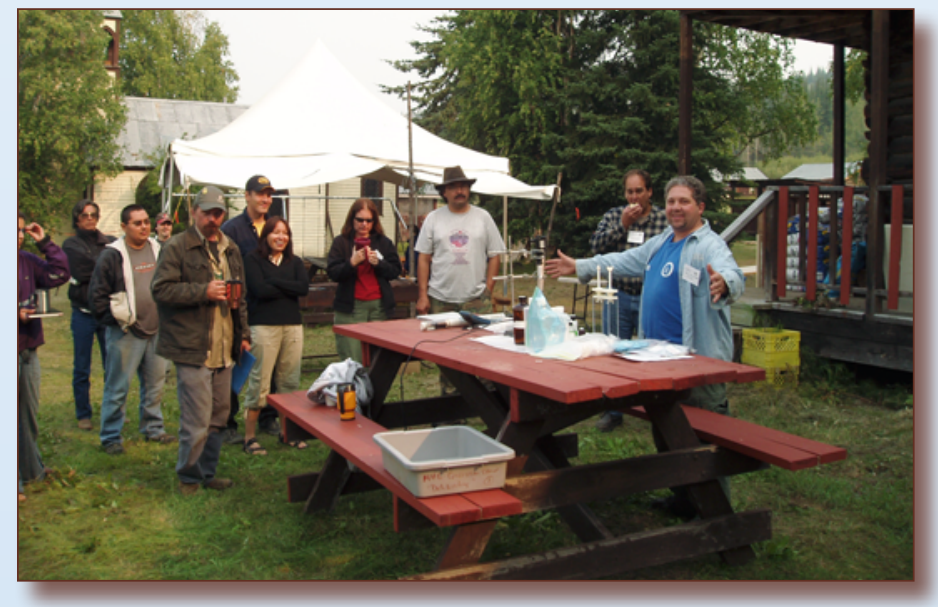

Water-quality sampling demonstration at the 2005 Summit, Moosehide, Yukon Territory.

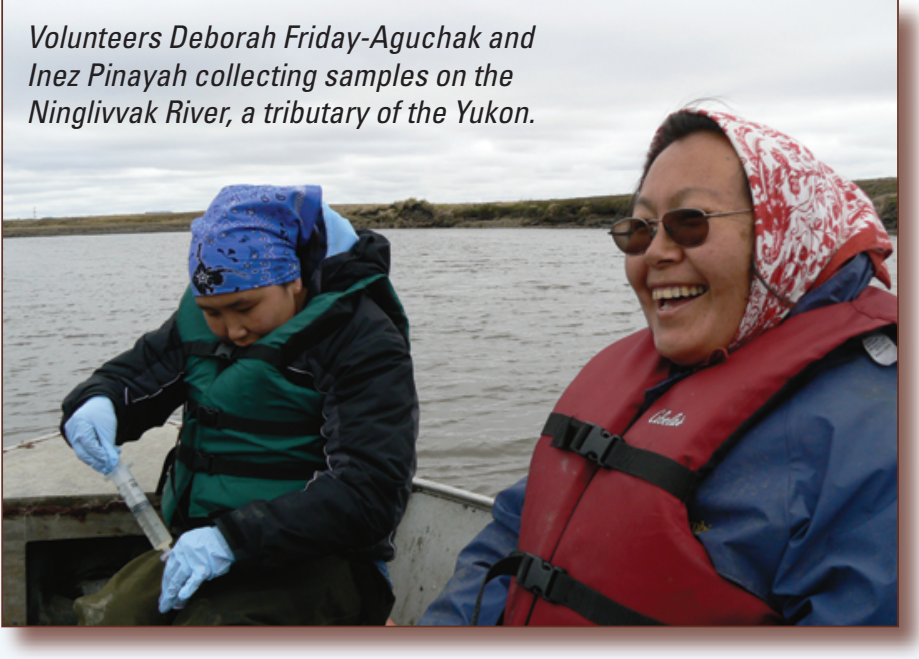

In early 2008, YRITWC secured a grant through the Northern Strategy Trust of Canada and began a partnership with the Government of Yukon. This partnership expanded the monitoring program to include the Yukon Territory covering the entire YRB from the headwaters near Whitehorse to the outlet at Pilot Station.

\section{Spreading the Word}

Attendance and presentation at both cultural and scientific meetings is essential to the continuing growth of the USGS/ YRITWC partnership. The USGS plays an active role in the YRITWC-sponsored biennial Summit meetings held throughout the Yukon River Basin. These Summits are attended by representatives of national and international Federal, State, local, and Tribal governments and serve multiple purposes, including the strengthening of relations with Tribal Councils and First Nations throughout the Yukon River Basin.

Attendance at scientific meetings also is recognized as critical to the growth of the USGS/YRITWC partnership. Since 2007, papers have been presented at several scientific forums (American Water Resources Association, Water and Restoration Conference, Fairbanks, Alaska, 2007; 6th National Water Quality Monitoring Council Conference, Atlantic City, New Jersey, 2008; and AGU Fall Meeting, San Francisco, California, 2008).

\section{Real Results}

Through this unique collaboration, the USGS 5-year baseline dataset covering 2001-2005 has been extended to a 9-year dataset. The 2001-2005 USGS data and citations are available online at:

http://pubs.usgs.gov/of/2003/ofr03427/
http://pubs.usgs.gov/of/2005/1199/
http://pubs.usgs.gov/of/2005/1397/
http://pubs.usgs.gov/of/2006/1258/
http://pubs.usgs.gov/of/2007/1037/
http://pubs.usgs.gov/of/2006/1228/
http://pubs.usgs.gov/of/2007/1197/

The 2006-2008 USGS/YRITWC data are available online at: http://yritwc.dsys.cal

Figure 3 shows dissolved organic carbon (DOC) plotted with discharge (Q) for 9 years on the Yukon River at Pilot, Alaska. The green triangles represent USGS data collected 
from 2000-2005 and the blue squares represent YRITWC data collected from 2006-2008 by Tribal and community members under the direction of the YRITWC. The consistency of the annual mean averages of both datasets demonstrates proper execution of sampling and processing protocols. Moreover, the variation in concentrations over the 9-year record demonstrates the importance for long-term data collection to assess the effects of climate change and extension of record from 5 to 9 years.

An important and critical component of this research is the availability of continuous records of streamflow and discharge at USGS streamgages, such as Pilot Station in the YRB. Without these data, the calculation of constituent loads would not be possible.

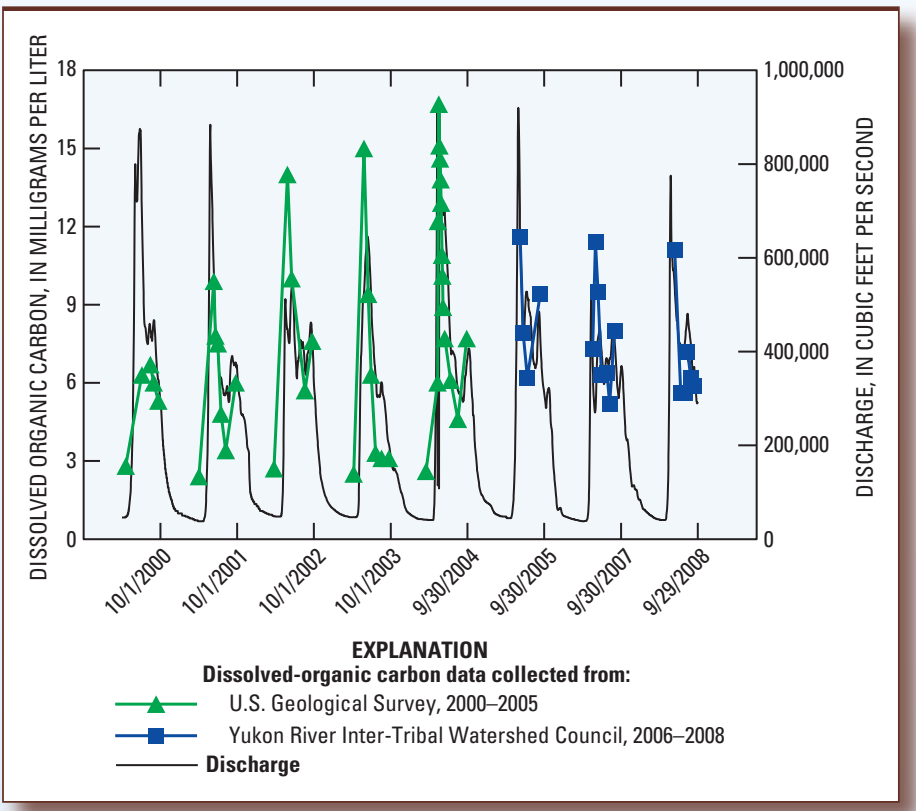

Figure 3. Dissolved organic carbon (DOC) plotted with discharge for 9 years on the Yukon River at Pilot Station, Alaska.

\section{A Unique Partnership}

The continuing collection of water-quality data from the Yukon River and selected major tributaries at a basin-wide scale would not be possible without the YRITWC/USGS partnership and community involvement. This partnership requires a coordinated effort from field sites through the laboratory and finally to published results in the form of peer-reviewed scientific products. In the field, qualified volunteer water technicians and YRITWC staff rise to the challenge of weather and the elements while confronting the logistical difficulties often associated with field work.

Victor Tonuchuk, Jr., a YRITWC volunteer, filtering a water sample on the shoreline of the Yukon River during peak spring flows, May 2008, Kotlik, Alaska.

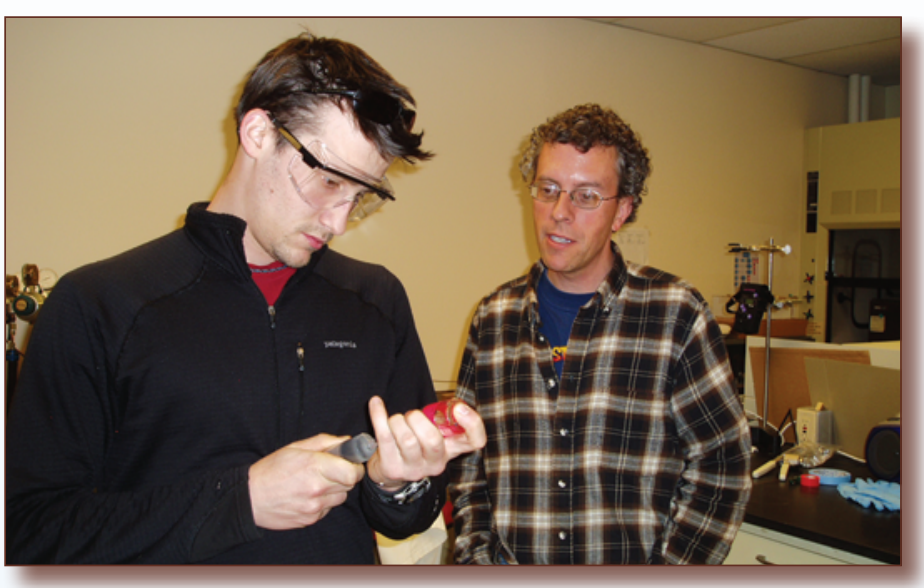

Mark Dornblaser, USGS (right), training Bryan Maracle, YRITWC, on the collection and proper technique for sampling greenhouse gases from water samples, USGS, National Research Program, Boulder, Colorado, research laboratory, October 2007.

\section{Summary}

Since its beginnings in 2005, the YRITWC/USGS partnership continues to strengthen and grow. Over the years, the water-quality monitoring program has expanded in spatial and temporal cover throughout the Yukon River Basin in Alaska and Canada.

Table 1 lists the number of sampling locations and frequency of sampling for the last 4 years throughout the entire YRB.

The scientific data and publications are available to governments, Native and Tribal organizations, and the general public to make informed decisions about the effects of predicted climate change and the future management of natural resources.

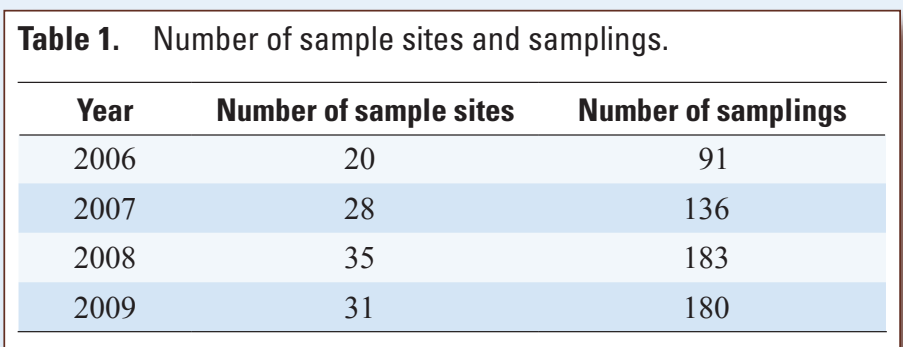

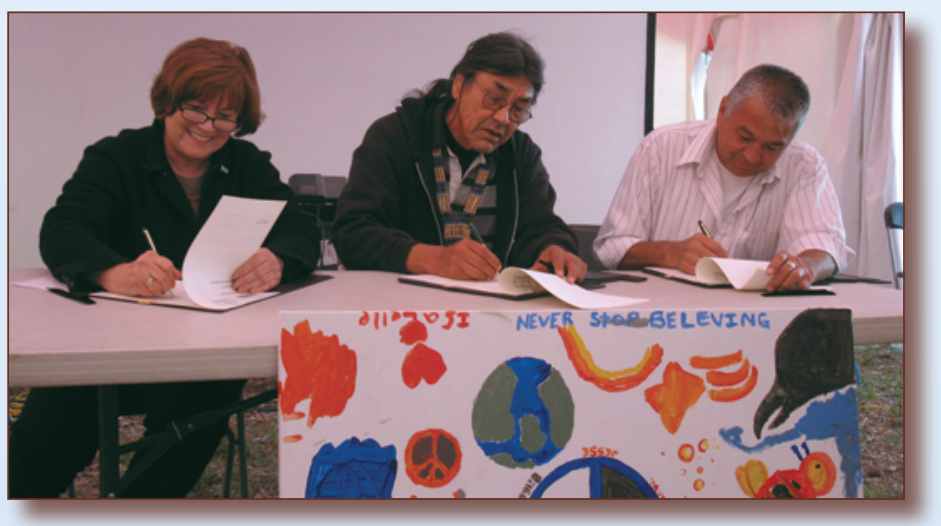

From left to right, Suzette Kimball, acting USGS Director, Clarence Alexander, Alaska Board Chairman (Yukon Flats), and Carl Sidney, Yukon Board Chairman, Dahka Tlingit Nation, signing a Memorandum of Understanding between the USGS and the YRITWC during closing ceremonies of the 7th Biennial Summit, Whitehorse, Yukon Territories, August 2009. 


\section{References Cited}

Hinzman and others, 2005, Evidence and implications of recent climate change in northern Alaska and other Arctic regions: Climatic Change, v. 72, no. 3, p. 251-298.

Jorgenson, M.T., Shur, Y.L., Pullman, E.R., 2006, Abrupt increase in permafrost degradation in Arctic Alaska: Geophysical Research Letters, v. 33, no. 2, 4 p.

Kane, E.S., Harden, J.W., Kasischke, E.S, Turetsky, M.R., and Manies, K.L., 2006, Soil drainage and topographic influences on wildfire consumption of soil organic carbon in boreal forests-Implications for carbon stability: Eos Transactions, American Geophysical Union, v. 87, no. 52, Fall Meeting Supplement, Abstract B21A-1011.

Striegl, R.G., Aiken, G.R., Dornblaser, M.M., Raymond, P.A., Wickland, K.P., 2005, A decrease in discharge-normalized DOC export by the Yukon River during summer through autumn: Geophysical Research Letters, v. 32, L21413.

Striegl, R.G., Dornblaser, M.M., Aiken, G.R., Wickland, K.P., and Raymond, P.A., 2007, Carbon export and cycling by the Yukon, Tanana, and Porcupine Rivers, Alaska, 200 -2005: Water Resources Research, v. 43, W02411, doi:10.1029/2006WR005201, 9 p.

U.S. Geological Survey, variously dated, National field manual for the collection of water-quality data: U.S. Geological Survey Techniques of Water-Resources Investigations, book 9 , chaps. A1-A9, available online at http://pubs.water.usgs.gov/ twri9A.

Walvoord, M.A., and Striegl, R.G., 2007, Increased groundwater to stream discharge from permafrost thawing in the Yukon River basin-Potential impacts on lateral export of carbon and nitrogen: Geophysical Research Letters, v. 34, L12402.

\section{Acknowledgments}

It is an honor to acknowledge all the participating Tribes, First Nations, and members of local communities. Their dedication and investment to this partnership is a testament to the importance of environmental issues to Arctic communities.

Indigenous communities involved:

- Arctic Village Council

- Carcross Tagish First Nation

- Council of Athabascan

Tribal Governments

- Eagle Traditional Council

- Gwichyaa Gwich'in Tribal Government

- Iqurmiut Tribal Council

- Kotlik Traditional Council

- Koyukuk Tribal Council

- Kwanlin Dun First Nation

- Little Salmon/Carmacks First Nation

- Louden Tribal Council

- Nacho Nyak Dun First Nation
- Ohogamiut Traditional Council

- Pilot Station Traditional Council

- Ruby Tribal Council

- Stebbins IRA Council

- Ta'an First Nation

- Taku River Tlingit First Nation

- Teslin Tlingit Council First Nation

- Tr'ondek Hwech'in First Nation

- Venetie Tribal Government

- Venetie Village Council

- Yupiit of Andreafski

\section{For additional information contact:}

Paul F. Schuster

U.S. Geological Survey

3215 Marine Street,

Suite E127

Boulder, Colorado 80303

Phone: (303) 541-3052

Fax: (303 541-3084

Email:pschuste@usgs.gov
Karonhiakta'tie Bryan Maracle Yukon River Inter-Tribal Watershed Council 815 2nd Avenue

Fairbanks, Alaska 99701

Phone: (907) 451-2546

Fax: (907) 451-2534

Email:bmaracle@yritwc.org

Participants of the March 2008 training workshop for volunteer water technicians after completing an under-ice sampling in conjunction with a discharge measurement made by the USGS Fairbanks field office staff, Tanana River at Nenana, Alaska.

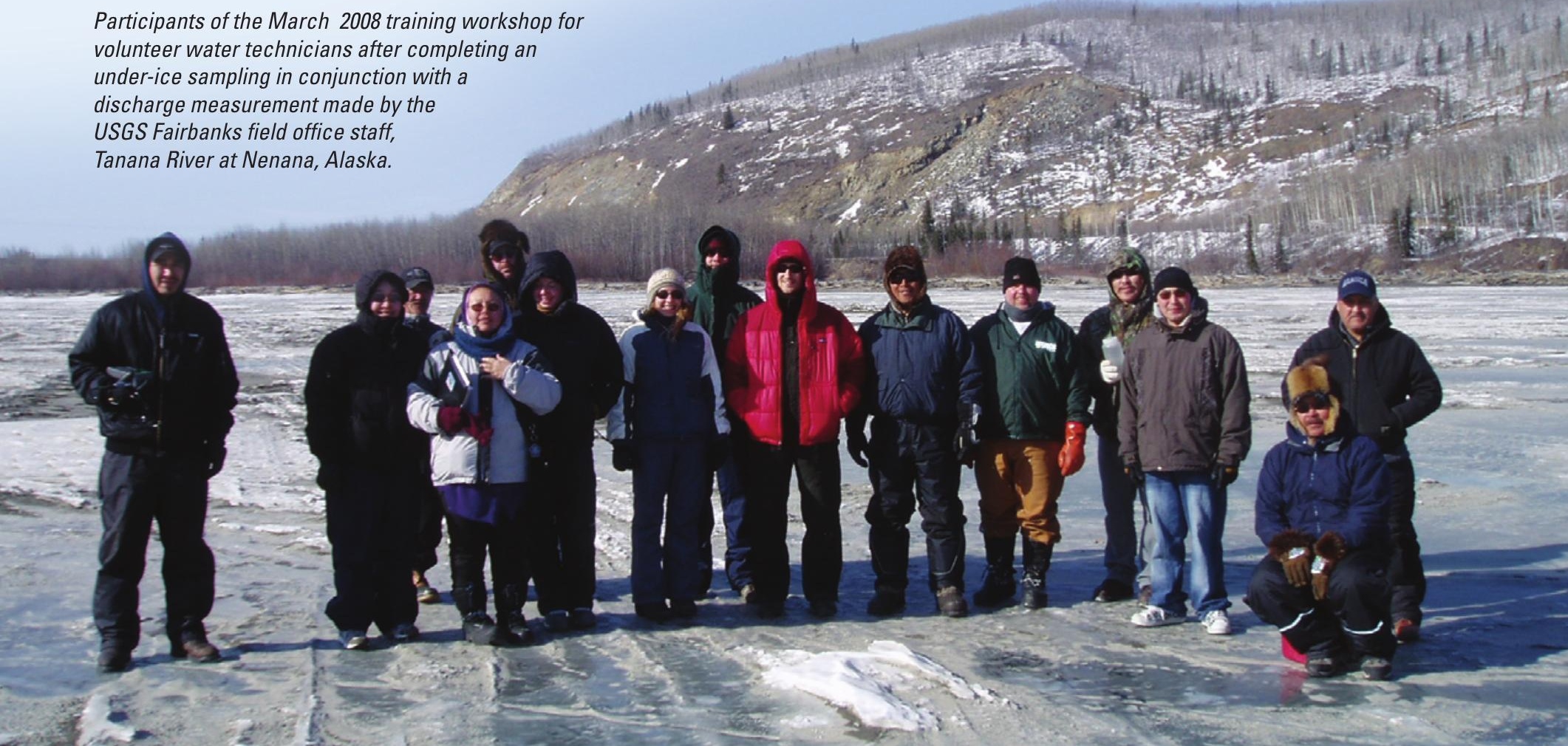

